\title{
A KÖNYVTÁROSOK FELKÉSZÍTÉSE VEZETÉSI FELADATOKRA: KOMPETENCIÁK KOMPLEX FELADATOKHOZ
}

\section{LEDA BULTRINI}

\section{Tartalmi összefoglalás}

A könyvtárakban megvan az a potenciál, hogy sikeresen szembenézzenek a nehéz idők kihívásaival. Ennek az a kulcsa, hogy a könyvtárakat ne determinált, hanem dinamikus, komplex rendszerekként kezeljék, és ennek megfelelöen vezessék. Azúj könyvtári vezetöknek ezzel tisztában kell lenniük, és olyan képzést kell kapniuk, hogy inkább közvetítök legyenek, mint kontrollerek, és a változások létrehozására tudjanak összpontositani, ahelyett, hogy szabályokat hoznának létre; figyeljék a jeleket, hallgassanak a rendszerre és környezetére, és lépjenek túl a merev, üzleties menedzseri megközelítésen.

https://doi.org/10.46280/KOMPKONF.2020.Bultrini

A könyvtárak más intézményeknél korábban szembesültek az ún. posztindusztriális társadalom meghatározó jellemzőivel: a dinamikus és mindent átszövő információtechnológiákkal, a földrajzi és közigazgatási területeken túlmutató működési összefüggésekkel, az információ és a globalizáció exponenciális növekedésével.

Emellett hagyományaikból fakad, hogy olyan jellemzőkkel és készségekkel rendelkeznek, amelyek miatt alkalmasak arra, hogy élére álljanak a társadalmi-kulturális valóságunkra kiható átalakulási folyamatoknak. Azonban, ahogy az infokommunikációs technológiák első robbanása idején megtörtént, nem mindig nyilvánvaló, hogy a könyvtárak készek és képesek arra - legalábbis a vezetés szintjén -, hogy kialakítsák saját víziójukat és egy paradigmaváltást hajtsanak végre; gyakran előfordul, hogy nem tűnnek elég magabiztosnak ahhoz, hogy vezessék ezt a folyamatot. A vezetés területén átengedik a terepet más szakmai közösségeknek, amelyek láthatóan birtokában vannak a szükséges megoldásoknak.

Amikor a könyvtári közösség a könyvtárosok intézményvezetői felkészítéséhez szükséges eszközöket és kompetenciákat veszi szemügyre, tulajdonképpen erősen befolyásolja a „menedzserializmus" ideológiája. Hogy szembenézzenek a finanszírozási megszorításokkal és versenyre keljenek más, erőteljes szereplőkkel - annak érdekében, hogy hatékonnyá tegyék a közszolgáltatásokat, ahogy az a régi „új” közigazgatás keretében tipikus volt -, a könyvtárosok átveszik az olyan, fösodorba tartozó megközelítéseket és módszereket, mint amilyenek a verseny, a célvezérelt menedzsment és az ösztönzésen alapuló motiváció, erre példa a teljesítmény szerinti fizetés, a teljesítményértékelés. 
A kockázat abban rejlik, hogy új könyvtári vezetőket kell kinevelni ahhoz, hogy tisztelettel viszonyuljanak az üzleti menedzsment-megközelítéshez, még ha vitatják is ezt a megközelítést azon a kontextuson belül, amelyből ered. A könyvtáraknak inkább tudatosítaniuk kell azokat a kereteket, eszközöket és tapasztalatokat, amelyekkel már rendelkeznek, és azt az igényt, hogy ezeket alkalmazzák egy új paradigmán belül, új gondolatokat és új mentális kereteket hozzátéve.

A komplexitás az a kulcsszó, amelyre hivatkozva a könyvtárak ezt az eltérő megközelítést kiépíthetik, és élhetnek jellegzetes képességeikkel.

\section{Röviden a komplexitásról}

„A komplexitást egyre inkább a való világ rendszereinek jellemzőjeként értelmezik, nem pedig pusztán matematikai jelenségként [...]. Gondolkodásmódunk, értékeink és elemzö eszközeink javarészt [...] a világ leegyszerüsitett szemléletében gyökereznek, ez talán elegendö volt a múltban, de ma egyre kevésbé kielégitö. Az elmúlt, megközelítöleg egy évtizedben az alacsony költségü számitási megoldások, a fizikai és biológiai rendszerek komplexitásának eszközei és a róluk való vélekedés új szempontokat adtak az elemzéshez, amelyek információkkal szolgálnak a döntéshozatalhoz. Ezek segitségével újra szemügyre vehetjük az ijesztö problémákat, és olyan, stabilabb megoldásokhoz, kevesebb nem kívánt következményhez, továbbá olyan megoldásokhoz juthatunk el, amelyek az érintettek szélesebb köre számára elfogadhatóak". ${ }^{1}$

Ahogy Manuel Manga sok évvel ezelött írta, „a világ megváltozott, és továbbra is nagyon mélyreható és zavarba ejtö változásokon megy át. A jövö már itt van, és a legtöbb ember, a vezetők és a nemzetek számára meglepetésként vagy sokként jelenik meg. Míg legtöbben napi gondjaikra összpontositják figyelmüket, a világunkat alakitó erök továbbra is egyaránt hordozzák a káoszt és a lehetöségeket, a válságot és az új világok lehetöségeit. Hogy az egyes intézmények miképpen profitálnak ezekböl a változásokból, az attól függ, hogy vezetöik milyen megfigyelök, és hogy ezek a vezetök milyen készségekkel és kompetenciákkal rendelkeznek".

Ez a két hosszú idézet arra szolgál, hogy megmagyarázzam, miért lehet fontos, hogy a komplexitás koncepciójának módszerével közelítsünk az új könyvtári vezetők számára szükséges új és sokrétủ kompetenciákhoz. A világ igen gyorsan változik, és olyan jelenségeket mutat, amelyek elkerülhetetlenül hatással vannak ránk: a gazdasági rendszer globalizációja, az infokommunikációs forradalom, bevált szociális gyakorlatainkat megzavarják a társadalmi változások, ami arra kényszerít bennünket, hogy alkalmazkodjunk az új valósághoz; és a természeti környezetet érő drámai változások. Azonban világnézetünket még mindig a szétforgácsoltság, a reaktív hozzáállás, az ellenőrzés hajszolása és a fenntartható gondolkodás hiánya jellemzi. Fritjof Capra a The web of life című művében ${ }^{3}$ tökéletesen

1 DON, Bruce: What can complexity teach us about policy. RAND and the Woodrow Wilson Center for Scholars seminar series. Decision making in complex systems. Lessons for public policy. Washington, DC, February 2002.

2 MANGA, Manuel: The evolutionary leader of the future. A new observer and designer of organizations and social systems = Center for Evolutionary Leadership, paper, 1999. 1. p.

3 CAPRA, Fritjof: The web of life. London, HarperCollins, 1996. 4. p. 
leírja ezt az „észlelési válságot”, ezt a tartós magatartást, amellyel a világunkat észleljük és intézményeinket megszervezzük mechanisztikus világnézettel, a paradigmákat az ipari forradalomból és a gépesítés korszakából merítve. A káosz, a bizonytalanság és az új valóság összefüggései új megközelítési módot és újfajta irányítást sürgetnek, amely képes kezelni az új, elöre nem látható kihívásokat.

A valóságos, természeti és emberi világ másfajta megközelítését a komplex rendszerekről való tudományos gondolkodás evolúciója hozta el számunkra, amit a számítógépek számítási kapacitásának óriási növekedése tett lehetővé.

A komplex rendszerek elméleteit fejlődésük három tengelye szerint lehet nyomon követni, ezek: a nem lineáris rendszerek elmélete, a neurális hálózatként való megközelítés és a megosztott vagy önszervező rendszerek elmélete alapján.

A múlt század elején Henri Poincaré elsőként alkalmazta a „komplex rendszer” fogalmát, amikor az égitestek pályagörbéjének meghatározását szolgáló egyenletekkel dolgozott. Egy három bolygóból álló rendszer (azt gondolnánk, hogy ez nem is annyira bonyolult), amely nem lineáris interakcióban állt egymással, vezette rá, hogy matematikailag lehetetlen egzakt megoldást találni ezekre az egyenletekre. A rendszer viselkedése, ha egyszerü volt is és teljesen esetleges, komplex volt és meghatározhatatlan. ${ }^{4}$

Az ötvenes években a nem lineáris rendszerek vizsgálatában fontos szerepet játszott a mesterséges neurális hálózatok fejlesztése, amellyel azt modellezték, hogy müködnek a neuronok. A neurális hálózatok nem lineáris rendszerekként olyan klasszifikációs és extrapolációs tulajdonságokat mutattak, amelyek révén megjeleníthetők és megérthetők lettek a kognitív folyamatok.

A harmadik fontos lépést, amely nemcsak a kognitív, hanem a társadalmi rendszerek kielégítő modellezése felé is mutatott, a megosztott és önszervező rendszerek elmélete képviselte, arra a körülményre építve, hogy egy független és autonóm ágensek népességéből álló rendszert, amely helyi szinten interakciót végez, „önszerveződő” és „intelligens” globális viselkedés jellemez. ${ }^{5}$

Mire gondolunk, amikor „komplex rendszerekről” beszélünk? Egy lehetséges és hatékony, s ezért gyakran idézett ${ }^{6}$ meghatározás a következő: Komplex rendszer az a rendszer, amelynek nehéz, ha nem lehetetlen, a leírását korlátozott számú paraméterre vagy jellemzö változóra korlátozni anélkül, hogy lényeges globális funkcionális tulajdonságait elveszítenénk. ${ }^{7}$

4 POINCARÉ, Henri: Leçons de mécanique celeste. 3 tomes, 1905-1910. Republished by Jacques Gabay, Paris, 2003.

5 Rövid bevezetés a neurális hálózatokba: https://complexitylabs.io/neural-networks/, az önszervező rendszerekbe: https:// complexitylabs.io/self-organization-overvew/. Lásd még: HEYlighen, Francis: Complexity and self-organization. In: Marcia J. Bates, Mary Niles Maack (eds.): Encyclopedia of library and information science, Taylor \& Francis, 2009. 1215-1224. p. Forrás: https://doi.org/10.1081/E-ELIS3-120043869 [2018. november 4.]

6 Lásd például Sugumaran, Vijayan: Application of agents and intelligent information technologies. Hershey, PA, IGI Global, 2007. 68. p. Forrás: https://doi.org/10.4018/978-1-59904-265-7 [2018. november 4.]; Kissane, Dylan: Cleopatra's nose and complex international politics. In: Șefika Erçetin, Santo Șule Banerjee (eds.): Chaos, complexity and leadership 2013. Cham, Springer, 2015, 60. p. Forrás: https://doi.org/10.1007/978-3-319-09710-7_5 [2018. november 4.] stb.

7 PAVARD, Bernard: Complexity paradigm as a framework for the study of cooperative systems. = Revue d'intelligence artificielle, 16. 4-5. 2002. 419-442. pp. https://doi.org/10.3166/ria.16.419-442 [2018. november 4.] 
De számos definíció létezik, amelyek a rendszer különböző vonásait hangsúlyozzák, és valamennyiük szuggesztív az érvelésünk szempontjából. Richard Seel állította össze ezek reprezentatív jegyzékét: ${ }^{8}$

- ... egy rendszer, amely komplex, abban az értelemben, hogy számos független ágens sokféle módon interakcióban van egymással. ${ }^{9}$

- ... hogy egy komplex rendszer müködését megértsük, nemcsak részei müködését kell értenünk, hanem azt is, hogyan müködnek együtt, hogy egy egészet alkossanak. ${ }^{10}$

- ... általában véve az alapvetö komponensek és az alapvetö szabályok egyszerüek; a komplexitás abból adódik, hogy az egyszerü komponensek közül nagyon sok egyidejü interakcióban van egymással. A komplexitás valójában a szervezetben rejlik: abban a rengeteg lehetséges módban, ahogy a rendszer komponensei egymással interakciót végezhetnek. ${ }^{11}$

- A komplex adaptív rendszerek számos komponensböl vagy ágensböl állnak, amelyek interakcióban állnak egymással bizonyos szabályok szerint, amelyek megkövetelik, hogy megvizsgálják egymás müködését és arra reagáljanak, annak érdekében, hogy javuljon müködésük, és ily módon annak a rendszernek a müködése is, amelyet alkotnak. $^{12}$

- ... a komplex egész olyan tulajdonságokat mutathat, amelyek nem magyarázhatók meg részeiböl. A komplex egész, teljes mértékben nem misztikus értelemben, gyakran mutat olyan közös tulajdonságokat, „feltörekvö" jellemzöket, melyek a maguk jogán törvényszerüek. ${ }^{13}$

- A komplex adaptív rendszerek (CAS) elméletének megfogalmazása a szokásosnál nehezebb feladat, mert az egész CAS müködése több, mint részei müködésének a summája; a CAS rendszerek számos nem lineáris vonással rendelkeznek... ${ }^{14}$

- ... a komplexitás a rendszerben nem egy specifikus, azonositható helyen található. Mivel a komplexitás a rendszer komponensei közötti interakcióból adódik, a komplexitás magának a rendszernek a szintjén nyilvánul meg. Sem alsóbb szinten (egy forrásban), sem felsőbb szinten (egy-metaleírásban) nem lehet megragadni a komplexitás lényegét. ${ }^{15}$

Egy komplex rendszer nem azonos egy bonyolult rendszerrel. Egy repülőgép vagy egy számítógép más, mint egy ökológiai rendszer vagy egy társadalmi szerveződés: az előbbiek viselkedése megjósolható; ezzel ellentétben az utóbbi egymással interakcióban álló, önszerveződésre

8 SEEL, Richard: Complexity and organisation development. An introduction in new paradigm. Complexity, 1999.

9 WALDROP, M.: Complexity. The emerging science at the edge of order and chaos. New York, Simon \& Schuster Paperbacks, 1993. 11. $p$.

10 BAR-YAM, Yaneer: Dynamics of complex systems. Reading, Mass. Addison-Wesley, 1997. 1. p.

11 WOLFRAM, Stephent idézi Waldrop i. m. 1993. 86. p.

12 STACEY, Ralph: Complexity and creativity in organizations. San Francisco, Berrett-Koehler, 1996. 10. p.

13 KAUFFMAN, Stuart: At home in the universe. The search for laws of complexity. Harmondsworth, Penguin, 1996. 7-8. p.

14 HOLLAND, John H.: Hidden order. Reading, Mass, Helix, 1995. 5. p.

15 CILLIERS, Paul: Complexity and postmodernism. Understanding complex systems. London, Routledge, 1998. 2-3. p. 
utaló tulajdonságokat mutató részekből áll, $\mathrm{s}$ a teljes rendszerek a környezettel nem lineáris interakcióban vannak - más szóval viselkedésük elöre nem jósolható meg.

Azt javaslom, tekintsük a könyvtárakat valódi komplex rendszereknek, nemcsak, ahogy szoktuk, egyszerü interaktív rendszereknek, amelyek a környezetből inputot, forrásokat és visszajelzést kapnak, és amelyek az összetevő részeik és a külső világ között fennálló kapcsolatoknak köszönhetően müködnek. (Ez a meghatározás igaz a számítógépekre is: bonyolult, de nem komplex rendszerek.)

Nyilvánvaló, hogy ezt a megközelítést metaforaként javaslom, olyan értelemben, ahogy Gareth Morgan írta az intézményekröl. ${ }^{16} \mathrm{Nem}$ azt javaslom, hogy a könyvtárakat matematikai eszközökkel, megfelelő egyenletekkel vagy más számítástechnikai eszközökkel modellezzük. (Ez nagyon érdekes elemzés lenne, de talán nem igazán értenék a könyvtárosok.)

Ha az „imázs” megfelelö a könyvtárak számára, úttörő jellegünek kell lennie, javaslatokkal kell szolgálnia és talán még többet, ajánlásokat is, hogy jobban meg tudjuk érteni környezetünket és szembe tudjunk nézni a jövővel.

Egy komplex rendszert négy fö jellemzője alapján lehet leírni:

- Nem lehet egy komplex rendszer működését megjósolni, még akkor sem, ha komponenseinek funkciói teljesen ismertek. Egy komplex rendszer nem-determinisztikus.

- Nem lehet egy komplex rendszer tulajdonságait vizsgálni (funkcionálisan stabil részeknek tekintett) összetevőinek külön-külön vizsgálatával. Mint már említettük, a rendszert az teheti újrastrukturálhatóvá funkcionális szempontból, hogy a részek képesek az önszerveződésre, és a rendszer interakcióban van a környezettel. Egy komplex rendszer funkcionálisan korlátozott szétbonthatósággal bír.

- Ami a megosztott rendszert illeti, vannak a komplex rendszernek olyan tulajdonságai, amelyek nem állapíthatók meg pontosan, hasonlóképpen az elemeik közötti kapcsolathoz, amelyek nem lineárisak, pozitív és negatív visszacsatolási mechanizmusokkal rendelkeznek.

- Némelyik tulajdonság, amely „feltűnhet” egy komplex rendszerben, nem jósolható meg elöre vagy írható le a rendszer részeinek ismerete alapján.

Ahogy az intézményekre (köztük a könyvtárakra) tekintünk, a társadalmi-kognitív folyamatok nem determinizmusát (vagy gyakorlatiasan fogalmazva, azt a kellemetlen hajlamot, amelyet ezek néha felmutatnak, amikor elképzeléseinktől és a programjainktól eltérően müködnek) gyakran tulajdonítják annak, hogy a megfigyelö nem ismeri a vizsgált rendszert, és/vagy elöre nem látható okok (pl. külső események vagy zaj stb.) rendszerzavart okoznak. A komplex társadalmi-technikai rendszerek tulajdonságainak elemzése viszont éppen azt mondja, hogy a nem determinizmusnak fontos funkcionális szerepe lehet.

A káoszelmélet lehet a magyarázat arra a tényre, hogy a kezdeti körülményeikre érzékeny rendszerekben e körülmények kis változása hosszabb távon drámai módon (és kiszámíthatatlanul) megváltoztathatja a rendszer működését. Az egyszerű szabályok rendet

16 MORGAN, Gareth: Images of organization. Updated edition. Thousand Oaks, Sage Publications, 2015. 
eredményezhetnek, különösen stabil rendet, de az egyszerü szabályok néhány csoportja ehelyett változatosságot, és akár káoszt is okozhat, pontosan a nem determinizmus miatt.

A káoszelmélet egyik kulcsfontosságú és érdekes koncepciója kifejtendő érvelésem számára a „káosz pereme”, amely szerint a rendszer legjobb teljesítménye, potenciáljának maximuma, a legösszetettebb számítások pontosan a káosz peremén figyelhetők meg. A káosz peremén egy változás könnyen és spontán bekövetkezhet egy rendszerben, és a kaotikus állapotba való belépést követően a rendszer újraszervezheti magát, magasabb szintü komplexitás felé haladva, vagy elveszítheti szervezettségét és széteshet.

Ha a valós élethelyzeteket (például a mi esetünkben a könyvtári szervezeteket) komplex rendszernek tételezzük, a káosz peremének létezése és lehetséges meghosszabbítása, a rend és a rendetlenség között átmeneti fázisban létező evolúciós tér felfedik intuitív képüket. Általános értelemben a káosz peremének elmélete arra késztet bennünket, hogy kevésbé féljünk attól, amit nem tudunk teljesen ellenőrizni, eltérve a megszokott eljárásoktól; kevésbé féljünk a szorongás instabilitásától és a véletlenszerűségtől, ami szükségszerűen létrejön, és inkább éljünk a kreativitás és a termelékenység növekedésével, melyek e helyzetből adódhatnak. Egyébként mind az instabilitást, mind a szorongást, az ágensek sokaságával (információáramlás, összekapcsolhatóság) együtt „kulcsváltozókként” lehet megjeleníteni, amelyek jelentős hatással vannak egy szervezet felkészültségére és változási képességére. ${ }^{17}$

A komplex rendszereknek azt a jellemzőjét, hogy funkcionálisan stabil részeik alapján előre nem jelezhető tulajdonságokkal rendelkeznek, nehéz intuitívan megérteni, mivel ez ellentmond a domináns funkcionális-analitikus kultúra alapelveinek, amely szerint, ha egy rendszer funkcionálisan lebontható, akkor globális müködése teljességgel kikövetkeztethető részegységeinek müködése alapján. Ha ismerjük a számítógép egyes elemeinek funkcióját, kiszámíthatjuk a számítógép globális működését egyes elemei működésének kombinációja eredményeként. Ezzel szemben egy komplex rendszer összetevői közötti kapcsolatok és kölcsönhatások dinamikus jellege és összetevői funkcióinak mobil jellege lehetetlenné teszik, hogy egy komplex rendszert funkcionálisan stabilnak és leírhatónak tekintsünk.

\section{Miért komplexek a könyvtárak mint társadalmi-kognitív rendszerek}

Idézzük fel a komplex rendszerek jellemzőit, melyeket gyorsan átvizsgáltunk, hogy a könyvtárakat a komplex megközelítésbe helyezzük el.

Egy komplex környezetben tevékenykedő humán ágens, a könyvtáros, ritkán tudja elmagyarázni pontosan, mit csinál, hogyan csinálja, és miért, ha nem éppen egy adott helyzetben kérdezzük (a probléma kontextusában). Ez azt jelenti, hogy a döntéshozatali folyamatnak (és általában a megismerésnek) teljes, szabályokon alapuló modellje nem lehetséges, nem létezik.

17 STACEY, Ralph: Complexity and creativity in organizations, 1996. ; SEEL, Richard: Complexity and organisation development. An introduction. 1999. 
Egyszerű eset, amikor egy könyvtáros egy felhasználóval vagy egy információs rendszerrel kölcsönhatásba lép, és eldönti, hogyan végzi el a keresést, hogy a legjobban kielégítse a felhasználó igényeit, de az egyértelmű, hogy komplex környezetben nem lehet pontosan megmagyarázni vagy meghatározni a szabályokat a döntéshozatali folyamatra nézve. Ezen kívül figyelembe vehetnénk a felhasználók szerepének és viselkedésének jelentőségét, ugyanakkor kiszámíthatatlanságát, és azt, hogy lehetetlen meghatározni és leírni azokat a szabályokat, amelyeket be kellene tartaniuk.

A komplex rendszerek nyitottak: ezért nagyon nehéz meghatározni egy komplex rendszer határait. A határ inkább a megfigyelő szükségleteitől, a szereplőktől és a kontextustól függ, mintsem a rendszer benső tulajdonságaitól.

A könyvtárakban a környezettel való kapcsolatok különbözőek és sokkal intenzívebbek, mint egy üzleti vállalkozás vagy más szolgáltatásokat nyújtó szervezetek input-output folyamatai. A csere beépül a szolgáltatásokba, ahogy magukat strukturálják. Ugyanakkor nyilvánvalónak tekintjük a könyvtári felhasználókhoz füződő viszonyokat és interakciókat attól a pillanattól, amikor a szolgáltatás elindul, de figyelembe kell venni például a szállítókkal vagy a kiadókkal végzett interakciókat is (például a megtekintésre küldött könyvszállítmányok hatékony kezelése érdekében).

Ha a könyvtárakról mint a rendszerként jellemezhető elosztott tudáshálózat részéről szeretnénk képet kapni, az információáramlást (annak tartósságát és növekedését) a könyvtárosok, felhasználók, kiadók és a beszállítók által alkotott hálózat csomópontjain keresztül tekinthetjük át, az interakcióknak és a visszajelzési mechanizmusoknak köszönhetően. Emellett figyelembe kell vennünk a más könyvtárakban és intézményekben dolgozókkal fennálló kapcsolatokat is. Az interperszonális kapcsolatokon túlmenően megfontolandóak a második szintű interakciók is a weben elérhető eszközök és anyagok révén, amelyek egyúttal az információk, ismeretek és „alkotások” olyan repozitóriumai, amelyek támogatják egy jelentős mértékben osztott rendszer kognitív tulajdonságainak reprezentációját (mint például a probléma memorizálását és strukturálását stb.).

Arra következtethetünk, hogy a könyvtárak határai valóban nagyon „gyengék”, és ha a határok gyengesége egy rendszer nyitottságának a kulcsa, nyilvánvaló, hogy milyen a könyvtári rendszer természete.

\section{Az új közigazgatás és a könyvtárak}

Ha a könyvtárat komplex rendszernek tekintjük, annak számos következménye van az irányítás módjára nézve. Ugyanabban az időben, amikor létrejön az a gondolat, hogy a komplexitás átszövi a való világ rendszereit, néhány menedzsment eszköz széles körű alkalmazását látjuk, melyek a profitorientált magánszektorból jutottak el a közigazgatásba, és a könyvtárakba mint (legalábbis többségükben) autonóm közintézményekbe vagy azok egyes részeibe/ fiókjaiba. 
Itt az irányítási technikáknak és gyakorlatoknak arról a komplexumáról beszélek, melyeket hagyományosan „új közigazgatásnak” nevezünk: kulcselemei közé tartozik a piacok növekvő használata, a közszolgáltatások nyújtása terén tapasztalható verseny, valamint a teljesítmény, a tervezés, a programozás és a kontrolling egyre nagyobb hangsúlya.

Az új közigazgatással itt általánosságban és egyszerüsítve egy olyan menedzsment-ideológiára utalunk, amelynek eszközeit részben, és a 80 -as évektől kezdődően a közszféra-reformjainak hullámához való tudatos csatlakozás miatt is világszerte alkalmaznak.

A kevesebb közfinanszírozás, a szigorúbb ügyfelek, a más információforrásokkal való verseny, a tudás gazdasági értéke a könyvtárakat is olyan új „kulcsok” keresésére készteti, amelyek segíthetnek abban a könyvtáraknak, hogy a közszolgáltatásokat hatékonnyá és eredményessé tegyék, és szembenézzenek a változó környezettel.

Ahogy korábban már említettem, a könyvtárak olyan kulturális helyzettel szembesülnek, melyet az információs és kommunikációs technológia (IKT) első robbanásához hasonlíthatunk. Ezt a nagyon erős áramlatot a szakemberek idézik elő - magabiztosan és láthatólag kétségek nélkül. Vonzó javaslatok, a szükségesség érzete, nincs már alternatíva (bizonyos technikákat „el kell fogadnunk”), néha csodálatos eredmények ígéretei (és elvárásai) miatt. Ahogy az információs forradalom és az internetrobbanás esetében is, a könyvtáraknak természetesen nyitottnak kell lenniük minden jobbító szándékú javaslattal és ajánlattal (lehetőséggel) szemben, amelyek más szakmai ágazatokból érkeznek (ebben az esetben) a menedzsment eszközök alkalmazásából adódóan, de új szemszögből is újra kell gondolkodniuk magukról. Elemezniük azt, hogy a bennük rejlő tudás, készségek, tapasztalatok, valamint az eddig kiaknázott strukturális jellemzők nyújtanak-e olyan módszereket és eszközöket, amelyek jobban illenek a komplexitás kihívásaihoz, és melyekkel el tudnak kezdeni dolgozni.

\section{Másfajta kilátások a könyvtárvezetők számára}

Egy menedzserre vagy vezetőre gyakran úgy tekintenek, mint egy szervezet „kontrollerére”. Ahhoz, hogy egy rendszert teljesen ellenőrizni tudjunk, annak elemeit, kölcsönhatásait, reakcióit teljesen egészében értenünk kell. Ha elfogadjuk, hogy egy komplex rendszer esetében lehetetlen ellenőrizni, mi történik a rendszerrel, akkor mérlegelnünk kell ennek következményeit a menedzsment szerepére nézve. Talán jobb megközelítés lenne, ha a menedzsert segítőnek vagy a „változást lehetővé tevő tényezőnek” tekintenénk, aki a megfelelő feltételeket tudja biztosítani a fejlődéshez a szervezet számára.

Általános értelemben a lefontosabbnak azt a képességet kell tartanunk, amit „változásra való készültségnek" nevezhetnénk: biztosak lehetünk abban, hogy mindig követnünk kell a kontextus fejlődését, annak részeként, azt és általa befolyásolva, hogy a legjobb választ tudjuk adni a felmerülő igényekre, alkalmazkodva a felmerülő megszorításokhoz. Hogy a komplexitás nyelvezetén (és ideológiáján) belül maradjunk, nem remélhetjük, hogy eldönthetjük a változás mikéntjét, és nem hihetünk abban, hogy a vezetők teszik lehetôvé azt, hogy a „dolgok megtörténjenek”. 
Ezért beszélünk az új minták „felbukkanásának” feltételeiről és arról, hogy a vezetés milyen szerepet játszik azoknak az „attraktoroknak” a befolyásolásában, akiket a rendszer „választ ki”. ${ }^{18}$

A környezetben zajló változásokra adott válaszként egy szervezet önszerveződési folyamaton mehet keresztül, hogy jobban megbirkózzon a környezetével. Új tulajdonságok (például új munkamódszerek, új szerepek és felelősségek) jelenthetnek meg. A komplex rendszerekről azt állítják, hogy magukat szervezik át attraktornak. Ha lehetetlen kijelölni az attraktort, a szervezet legalábbis valamilyen módon befolyásolni tudja az attraktor kiválasztását.

A „változásra való készültség” fö tényezői az összekapcsolhatóság, az ágensek sokfélesége és az információáramlás mértéke, valamint más, a humán szervezetekre jellemző befolyásoló elemek, mint például a szorongás miatti behatároltság vagy a teljesítménykülönbség (azaz a gátló tényezők hiánya).

Az összekapcsolhatóság a könyvtárak strukturális jellemzője. Az interakció mintái sokszor és nagyon sokat változtak a könyvtári univerzumban az elmúlt évtizedekben: a hálózati munka már megvalósult a könyvtárak számára már jóval azelőtt, hogy a társadalmi, politikai, közigazgatási és gazdasági változások arra késztették a politikai tudományokat, hogy a kormányzási megközelítést kifejlesszék, még mielőtt létrejöttek volna a közösségi hálózatok.

Ezen a ponton azt hihetnénk, hogy az „összekapcsolhatóságból soha nem elég”, de valójában az összekapcsolhatóság homogén kontextusban túlságosan magas lehet, kizárva a sokféleséget és a csoportos gondolkodást, ami a változást akadályozza. Másrészről a saját kultúrájuk csoportosítás révén történő fejlesztése a szerepük helyes értelmezése felől nézve normális és funkcionális dolog. Ezért a könyvtáraknak újra kell gondolniuk azt a készséget és attitűdöt, amellyel már rendelkeznek, hogy jobban alkalmazzák azokat az új kihívásokra.

Minél nagyobb a szervezet sokfélesége, annál nagyobb a „lehetőség tér”, amelyet feltárhat. Amire szükség van, az a - kulturális, intellektuális, emocionális - sokféleség (vagy magukban az ágensekben, vagy a köztük fennálló kapcsolatok természetében). A sokféleség önmagában nem vezet minták kialakulásához, hanem anarchiát és konfliktust okozhat, de a többi feltétellel összhangban éltető szerepe lehet.

A korábbi elemekhez (összekapcsolhatóság és hálózatok) viszonyítva a sokszínűség a könyvtári rendszerekben konkrét dimenziót nyerhet: a hálózatok lehetnek a sokféleség ösvényei a könyvtári rendszerekhez vezető könnyebb hozzáférésben.

Az információáramlás szempontjából egy stabil rendszer lassú áramlással tartható fenn, de sokkal erőteljesebb és gazdagabb áramlásra van szükség egy olyan rendszer esetében, amely messze van az egyensúlytól. Az ilyen, az egyensúlytól messze lévő feltételek azok, melyeken belül a hatékony szervezetek müködnek, mivel elég stabilak ahhoz, hogy túléljenek, megőrizzék azonosságukat, valamint elég változatosak és kiszámíthatatlanok, hogy képesek legyenek innovációra és a környezeti változásokhoz való alkalmazkodásra.

18 A matematikában és fizikában az attraktor olyan állapotot vagy többféle állapotot jelez, amely irányába egy dinamikus rendszer elmozdul, tekintet nélkül a kezdeti feltételekre. A szociológiában az attraktor olyan megoldást jelent, a sokféle lehetőség közül, amely felé egy helyzet halad, mivel társadalmi szinten funkcionálisabb. 
A könyvtárak inkább „állnak” információáramlásból, mint bármely más szervezet, és a könyvtárosok bármely más szakmai közösségnél jobban ismerik a szelektív információk fontosságát.

Amit gyorsan megemlítettünk, elegendő ahhoz, hogy a könyvtári oktatók és menedzserek más paradigmával szemléljék intézményeiket (és környezetüket), megismerjék őket, és olyan eszközöket találjanak, s olyan készségekkel éljenek, melyek jobban alkalmazkodnak a jelenlegi kihívásokhoz, mint a többi, más szakmai kontextusból származó megközelítés.

A stratégiai tervezés folyamatában a képességet nem szabad teljesen figyelmen kívül hagyni. Meg kell változtatnunk, hogy mire összpontosítunk, a szervezeti környezet figyelemmel kísérésére kell fókuszálni, nem pedig az elörejelzés pontosságára. Kritikusan kell megközelíteni néhány olyan, hiperracionális technikát, amelyek a változó folyamat blokkolását eredményezhetik. A célvezérelt menedzsment például, amely a magánszektor-menedzsmentből átvett eszközök egyike, a programszerủ és a mennyiségi dimenziókat hangsúlyozza, és könnyen alkalmazható a rugalmasság rovására. A „környezet vizsgálata” és a „forgatókönyvek kidolgozása” olyan lehetséges megközelítések, amelyek segítik a szervezetet a tudatosság növelésében és a közvetlen környezetéhez való kapcsolódás növelésében. El kell kerülnünk a felesleges elöírásszerű megközelítést, miközben a bizonytalanság egyre aktívabban van jelen a társadalmi rendszerekben. Henry Mintzberg most minden eddiginél jobban hangsúlyozza ezt a kockázatot. ${ }^{19} \mathrm{Az}$ ellenőrzés hierarchikus elvén túlmenően, amely a célvezérelt menedzsment lényeges vonása, a kontextus gyors és több irányú dinamikája döntéshozatali autonómiát követel a közös célok követéséhez.

\section{Következtetések}

Végezetül néhány gondolat a vezetésről: ha egy vezető csupán azzal foglalkozik, hogy elömozdítsa, hogy a dolgok megtörténjenek, arról nem is beszélve, hogy az intézményben kontrollerként működik, miközben az intézmény nem kontrollálható, mert nem determinisztikus és nem jósolható meg, mi fog történni, inkább legyen a változások motorja. Ezt a képességet kellene kiépítenünk, ami nem könnyü.

Aktívan kell figyelnie a rendszerre és összefüggéseire, késznek kell lennie arra, hogy „vegye" azokat a gyenge jeleket, amelyek az intézmény jövőjére nézve alkalmazkodási kihívásokat jeleznek. Módszeresen nyomon kell követnie a világot, hogy észlelje az új, váratlan, jelentős és kevésbé jelentős tendenciákat, amelyek konvergenciát, divergenciát, gyorsulást, lassulást vagy interaktivitást eredményeznek. Miközben a változás jeleit keressük, potenciális események jeleit a horizonton, közvetett, rejtett hatásokat, ne alkalmazzunk kemény és gyors szabályokat, amelyeket követünk, hogy „korrekt” értelmezésekre jussunk. Tudnunk

19 Lásd például Henri Mintzberg weblogjának két bejegyzését: Managing government, governing management, 2016. június 16-án http://www.mintzberg.org/blog/govt-mgmt, és: Need a strategy? Let them grow like weeds in the garden, 2018. június 29-én http://www.mintzberg.org/blog/need-a-strategy-let-them-grow-like-weeds-in-the-garden [2018. október 31.] 
kell, hogy kevés irányelv van arra nézve, hogyan végezzük a nyomon követést: a környezet nyomon követése - művészet.

Ugyanez a figyelmeztetés érvényes a rendszer belső viselkedésére való figyelésre: nincsenek szabályok, nincsenek irányelvek. Inkább személyes útról van szó, amely nagyobb öntudatossághoz és valakinek a határainak ismeretéhez vezet, ami segít, hogy megismerjük érzelmeinket, csökkentsük feszültségeinket, és szabadon engedjük azokat az energiákat, amelyek ahhoz szükségesek, hogy figyelmet fordítsunk a rendszer emberi tényezőjére.

Majd, ha megvizsgáljuk az egyéneket, mint az önmagukat kibővíteni képes élő rendszereket, e képesség ismerete végtelen intézményi gazdagsághoz vezethet.

A rendszerre való aktív figyelés azt jelenti, hogy fel tudjuk fogni a rendszeren belül az orientációra és döntésekre vonatkozó hálózatokat, jelzéseket és gondolatokat. És amikor egy jelzést felfogtunk, az azt követő intervenciónak soha nem szabad késlekednie. Az, hogy olvasni tudjuk a rendszerből érkező jelzéseket, azt is jelenti például, hogy alkalmazzuk az azonos végkifejlet elvét, miszerint nem kényszerítjük a rendszert arra, hogy a kijelölt irányt kövesse egy bizonyos cél eléréséhez, tudva, hogy ugyanazt a célt sokféle különböző kiindulási pontból is el lehet érni. (Vegyük azokat az országokat, amelyek nem hoztak létre telefonhálózatot, ma viszont ugyanolyan mobiltelefon-hálózattal rendelkeznek, mint a fejlett országok.) Vagy: ne kényszerítsük a rendszert arra, hogy egy meghatározott cél felé haladjon, amikor eltérések tapasztalhatók, mielőtt végiggondolnánk, hogy miért került sor az eltérésre, és nem lenne-e kívánatosabb egy új irányban haladni egy új cél felé.

A vezető számára ennek a kontextusnak kell diktálnia, hogy hogyan tanuljon, hogyan adja át tudását, hogyan vezessen, különben a kontextus nem követi őt.

Ezek a vezetők hajlandóak arra, hogy tekintetbe vegyék személyes életüket, intézményi életüket, és a világot, magukra vegyék a tanárok, coachok, a tanulási közösségek moderátorai és a tanulási infrastruktúrák tervezőinek szerepét. A vezetőket továbbra is foglalkoztatják majd a stratégiai irányok és hasonló kérdések, de egyre inkább az intézmény kollektív intelligenciáját fogják előmozdítani, mint a technikai és adaptációs változások megoldásának forrását. Felkészültnek kell lenniük arra, hogy elfogadják a kihívást, amely, hogy Ronald Heifetzet idézzem, ebben áll: „A vezetés nem jelent könnyü válaszokat”. ${ }^{20}$ 


\section{Irodalom}

BAR-YAM, Yaneer: Dynamics of complex systems. Reading, Mass, Addison-Wesley, 1997. 848 p.

CAPRA, Fritjof: The web of life. London, HarperCollins, 1996. 347 p.

CILLIERS, Paul: Complexity and postmodernism. Understanding complex systems. London, Routledge, $1998.157 \mathrm{p}$.

DON, Bruce: What can complexity teach us about policy, paper presented at RAND and the Woodrow Wilson Center for Scholars seminar series. Decision making in complex systems - Lessons for public policy, Washington, DC, February 2002.

HEIFETZ, Ronald A.: Leadership without easy answers. Cambridge, Mass., Belknap Press of Harvard University Press, 1994. 353 p.

HEYLIGHEN, Francis: Complexity and self-organization. In: Marcia J. Bates, Mary Niles Maack (eds.): Encyclopedia of library and information science. Taylor \& Francis, 2009, 1215-1224 p. Forrás: https://doi.org/10.1081/E-ELIS3-120043869 [2018. november 4.]

HOLLAND, John H.: Hidden order. Reading, Mass, Helix, 1995. 185 p.

KAUFFMAN, Stuart: At home in the universe. The search for laws of complexity. Harmondsworth, Penguin, 1996. $336 \mathrm{p}$.

KISSANE, Dylan: Cleopatra’s nose and complex international politics. In: Erçetin, Şefika, Şule Banerjee, Santo (eds.): Chaos, complexity and leadership 2013. Cham, Springer, 2015. 57-72 p. Forrás: https://doi.org/10.1007/978-3-319-09710-7_5 [2018. november 4.]

MANGA, Manuel: The evolutionary leader of the future. A new observer and designer of organizations and social systems = Center for Evolutionary Leadership, paper, 1999. Forrás: https://web.archive.org/web/20030312194343/http://www.evolutionleader.com:80/topics/papers/paper\%20-\%201999. doc [2018. november 4.]

MINTZBERG, Henry: Managing government, governing management. In: Henry Mintzberg, weblog, 2016. június 16. Forrás: http://www.mintzberg.org/blog/govt-mgmt [2018. november 4.]

MINTZBERG, Henry: Need a strategy? Let them grow like weeds in the garden. In: Henry Mintzberg, weblog, 2018. június 28. Forrás: http://www.mintzberg.org/blog/need-a-strategy-let-them-grow-likeweeds-in-the-garden [2018. november 4.]

MORGAN, Gareth: Images of organization. Updated edition. Thousand Oaks, Sage Publications, 2015. 504 p.

PAVARD, Bernard: Complexity paradigm as a framework for the study of cooperative systems. $=$ Revue d'intelligence artificielle 16. 4-5. 2002. 419-442 p. Forrás: www.researchgate.net/publication/228893485_ Complexity_and_Self-organization; https://doi.org/10.3166/ria.16.419-442 [2018. november 4.]

POINCARÉ, Henri: Leçons de mécanique celeste. 3 tomes, 1905-1910. Republished by Jacques Gabay, Paris, 2003 - New methods of celestial mechanics. 3 vols. (English trans.), [S. 1.], American Institute of Physics, 1993.

SEEL, Richard: Complexity and organisation development. An introduction. New paradigm. Complexity. 1999. Forrás: www.new-paradigm.co.uk/complex-od.htm [2018. november 4.]

STACEY, Ralph: Complexity and creativity in organizations. San Francisco, Berrett-Koehler, 1996. 312 p.

SUGUMARAN, Vijayan: Application of agents and intelligent information technologies. Hershey, PA, IGI Global, 2007, 392 p. Forrás: https://doi.org/10.4018/978-1-59904-265-7 [2018. november 4.]

WALDROP, M. Mitchell: Complexity. The emerging science at the edge of order and chaos. New York, Simon \& Schuster Paperbacks, 1993. 384 p. 
Leda Bultrini a laziói Regionális Környezetvédelmi Ügynökség (ARPA) Operációs rendszerek és tudásmenedzsment részlegének igazgatója, az Aquilai Egyetem Irányító tanácsának tagja. 2001-től az IFLA Osztályozási és Indexelési Szekciójának (Classification and Indexing Section), majd a Tudásmenedzsment Szekciójának (Knowledge Management Section) tagja, utóbbinak 2013 és 2017 között elnöke, végül jelenleg az Információtechnológia Szekció állandó bizottságának (SC Information Technology Section) tagja. Számos publikáció szerzője és szerkesztője, jelentős oktatási tapasztalatokat mondhat magáénak a dokumentáció, indexelés és tudásmenedzsment, a változások menedzselése, a programozás, valamint a projektmenedzsment témakörökben. Igen sok belföldi és nemzetközi konferencián vett részt ezekről a témákról. 